\title{
THE EMANCIPATION OF WOMEN \\ IN EIGHTEENTH-CENTURY ENGLISH LITERATURE
}

I.

The legal, economic, and social position of women in England during the 17th and 18th centuries is a topic in itself, and one far too wide-reaching for the scope of a single paper. The present study will concentrate on the image of woman and her emancipation as it is reflected in the theoretical and imaginative literature of the period. At the same time, particular consideration will be given to the connection between non-fictional writing and the development of belles-lettres.

Any consideration of the phenomenon of the feminist movement in the 17th and 18th centuries must start from the proposition that the discussion of parity or equal rights for men and women was limited to a small upper-class elite. The theoretical pamphlets and other documents all refer exclusively to the aristocrats and upper middle class. The idea that a farmer's wife or scullery maid might need emancipation was simply unthinkable at the time. The question of how the various social strata differed in this respect deserves further investigation. But in general we can say that the actual significance attributed to the problem of women's emancipation grows in direct proportion to the height of the social level: that is, the lower the social class, the less regard shown for questions of this kind.

In my opinion, the Restoration was far from being the death knell of the feminist movement, as has often been claimed. On the contrary, it had a stimulating and beneficial effect. Not only libertine courtiers accompanied King Charles when he returned to England, but also philosophers, poets, and serious writers familiar with what had been written on the feminist question. Hundreds of publications appeared on the subject in England 
after 1660 - a wealth of literature now nearly forgotten and unread, available only in the archives of the largest collections, siuch as that of the British Library. Some of the earliest publications are translations or adaptations from the French, and a good many must have caused a small sensation in England, for they were years in advance of anything written and published there so far. Only a few years after the Restoration, however, the first genuine English pamphlets on the subject began to appear. They testify to the fact that the liberal ideas of France had fallen upon fertile ground.

The truly epoch-making publications of the 18th century feminist movement appear to have been written by men in most c:ases. A prime example is The Ladies Calling, published anonymously in $1673^{1}$. Today it is commonly accepted that it was not urritten by Lady Parkington, as assumed by Ballard in 1752, but rather by a certain Richard Allestree, Regius Professor of Theology at Christ Church College, Oxford, and later Provost of Eton. The preface is particularly significant in its treatment of masculine prejudice and the devastating effect it has on the mind of woman. The author of The Ladies Calling argues that women have such a poor opinion of themselves and of the fair sex in general because men have instilled them with those very same convictions.

The World is much governed by estimation; and as applause encourages and exalts, so an universal contempt debases and dejects the Spirit. If it can once pass into a Maxim, that women are such silly or vicious creatures, it may put fair for the making them so indeed. Themselves may imbibe the common opinion, charge all their personal faults on their Sex, think they do but their kind, when indeed they most contradict it, and no more aspire to any thing worthy ${ }^{2}$.

Similar ideas are to be found in another polemical pamphlet translated from the French: The Woman as Good as the Man:

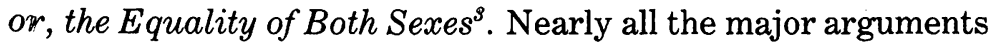
advanced by this publication are taken up again by later pam-

1 The Ladies Calling. By the Author of The Whole Duty of Man, \&c. (Oxford, 1673).

2 The Ladies Calling, Preface, n. p.

3 Written originally in French, And Translated into English by A. L. (London, 1677) [Licensed Aug. 20th 1676 Roger L' Estrange]. 
phlets, and repeated or elaborated upon. Masculine prejudice is the major target: man's opinion of the fair sex is due to nothing more than mere custom, and the male chauvinist viewpoint (to use a modern term) has neither a logical nor a scientific leg to stand on. The pamphlet goes on to point out that the essence of most masculine arguments is that things should stay the way they have always been and, indeed, as they are in practically every country in the world. If women were truly capable of greater things, surely men would not have held them back.

We shall find their mightiest Arguments reduced to this, That as to Women, matters have always past as now they go; which is a mark, that they are really such, as they are esteemed; And that, if they had been capable of Sciencies (sic), and Offices, Men would not have denyed them their shares ${ }^{4}$.

The counter-argument is that innate psychological or mental differences can hardly be the root of the problem, for both sexes share the same "natural turn" or habitat, which supplies them equally with nourishment and strength. Furthermore, women are born with the same capacity for talent and creativity as men. Given that natural environment and heredity seem equal, only education and the process of socialization can be pinpointed as the variable factors responsible for the difference between the sexes. Talent cannot grow of itself, but must be nurtured and cultivated. In the case of women, however, their mental and spiritual potential is systematically stifled from the very beginning:

... For now a Woman ... is from her Cradle kept at home, and as incapable of nobler Employment suffered only to knit, spin, or the like. And when she arrives at riper Years, is delivered to the Tyranny of a Jealous-pated Husband, or cloistered up in a Nunnery; all publick offices are denied them; implead to their own Names they must not, no Jurisdiction they can exercise, nor make any contract that is valid, without their Husband's licence; with other hard Impositions. By which unworthy partial Means they are forced to submit to Men, not out of natural or Divine Reason, but onely by Prevalency of Custom, Education, or some Tyrannical occasion ...5.

4 The Woman as Good as the Man, p. 7.

5 The Wonders of the Female World, or a General History of Women. Wherein By many hundreds of Examples is showed what Woman hath been from the first Ages of the World to these Times ... With 
If women are still designated as "the weaker sex" it is only because men have inconsiderately, and even brutally, kept them from doing anything to develop their minds. Rather, men have practically forced them to preoccupy themselves with trivia, such as fashionable clothing and trinkets.

What harm soever they do to the present Age, and whatever their share may be in the Vices and Follies of it, this we may justly blame the Men for; who take upon them to govern all Things, and condemn the Women to such an Education, as can render them but very little useful, and leaves them apt to be only mischievous and hurtful to the World. Certainly there cannot possibly be a greater oversight, than to banish them to those little, trivial and useless Employments which usually take up their precious Time of Leasure, and a single Life ${ }^{6}$.

The surprising and sometimes psychologically subtle conclusion drawn by a number of authors is that the difference between the sexes is "man-made", that is to say a product of the male mind. For if women are told again and again by those regarded as the highest authority (the clerics of the church) that they are evil and simple-minded by nature, then they are bound to see themselves and their actions in that light. Thus the best authors find it no more than just and charitable to open the eyes of women to the magnitude of their potential, in the hope of developing their self-awareness.

Much of the initiative towards equal rights and equal status for women originated with the Athenian Mercury ${ }^{7}$, one of the early moral weeklies, an all but forgotten magazine which has only rarely been consulted in connection with the feminist movement in 17th- and 18th-century England. Particularly interesting for our purposes is the discussion first taken up in the thirteenth issue of the third volume, in which one reader asked, in a letter to the editor, whether he and his authors were not doing great damage to the prestige of the magazine by dealing with what he termed "female impertinences". The

an Account of Sybils ... To which is added a Pleasant Discourse of Female Pre-eminence, or the Dignity and Excellency of that sex above the Male (London, 1683), p. 203-4.

6 The Excellent Woman, Described by her True Characters and their Opposites (London, 1695), Preface, p. IV (Done out of French by T. Dorrington).

7 The Athenian Mercury (London, 1671). 
editor retorted indignantly that there were a hundred male impertinences for every feminine one, and that the responses of his women readers were invariably interesting, well thought out, and deeply committed. Every such letter demanded time and effort to form an adequate reply.

This alone provides an unequivocal insight into the attitudes and intentions of the Athenian Mercury. Apparently the readership consisted largely of women: differences between the sexes are attributed to education and the social environment. Here a note is struck that continues to echo as, it might be said, a basso continuo throughout the first three decades of the eighteenth century:

... the women have as Nice a sense of things, and as good Judgements too, as most Men. 'Tis true, here in England, the Women are kept from all Learning, as the prophane Vulgar were of old, from the Misteries of the Ancient Religions; and therefore, are not generally so agreeable, in Conversation, to Men of Parts, and Sence, because, a new Dress, Dance, Play, \&c. is all they can discourse of ${ }^{8}$.

One of the decisive controversies conducted in several issues of the Athenian Mercury was the question of "whether it be proper for women to be learned". The editor suggested that women ought to possess at least a smattering of learning, the only question being degreee and kind. Some, he said, might deem it sufficient for a woman to be able to differentiate between her husband's trousers and a stranger's, or - more pointedly - between her husband's bed and the next man's. Others feel that she should be able to read a bit, and some even go so far as to grant her the liberty to read plays, novels and romances. The majority, however, oppose the idea of a woman reading philosophical works, on the ground that it would spoil her taste for wifely ways and duties. Of course, the fine and liberal arts were available only to those women who had the necessary time and leisure at their disposal anyway; that is to say, to those who were not forced to work for a living. Be that as it may, the final

8 The History of the Athenian Society, for the Resolving all Nice and Curious Questions ... written by Mr. Tate, Mr. Motteux, Mr. Richardson, and others (London, n. d. [1691?]), p. 26.

9 The Athenian Mercury, 18 (May 23, 1691). 
conclusion drawn by the Athenian Mercury amounts to a declaration of equal rights for women:

On the whole, since they have as noble souls as we, a finer Genius, and generally quicker Apprehensions, we see no reason why Women shoul'd not be learned now, as well as Madam Philips, Van Schurman and others have formerly been ${ }^{10}$.

This and related topics were taken up by all sorts of publications after the Athenian Mercury, and particularly by the "moral weeklies" which began to flourish after the turn of the 18th century. Examples are to be found in all the periodicals, above all in the Spectator, Tatler and Guardian. Their editors, Addison and Steele, are particularly notable for the strong liberal influence they had on the then current dicussion, and traces of their thought are clearly discernible up to the mid-century.

1739 saw the appearance of something entirely new, the Sophia Pamphlets ${ }^{11}$, which were to revolutionize the feminist movement and to become a lasting landmark of its progress. My personal impression is that the author was a woman, but this is still a matter of controversy. The arguments to the contrary are, at any rate, not conclusive. Sophia is conscious of her oppression and of the disadvantages of her position as a woman. Her aim is thus to inform, to persuade, to sound the call to arms. As a matter of fact, her arguments on the equality of the sexes go almost too far: for her the difference is purely physical, and even this is subject to further reservation:

It is a known truth, that the difference of sexes regards only the body, and that merely as it relates to the propagation of the Species. But the soul ... actuates all after the same manner ${ }^{12}$.

Thus inequality can only be the product of upbringing, education, and socialization:

the impressions of those external objects which surround us in different Circumstances ... ${ }^{13}$.

${ }^{10}$ The Athenian Mercury, 18 (May 23, 1691).

11 Woman not inferior to Man: or, a short and modest vindication of the natural right of the fair sex to a perfect equality of power, dignity and esteem, with the Men. By Sophia, a Person of Quality (London, 1739).

12 Woman not inferior to Man, p. 23-4.

${ }^{13}$ Woman not inferior to Man, p. 25. 
Given the same opportunities for learning, women would be capable of the same level of achievement as men, and that "in every branch of useful knowledge". In that very fact, however, lies the reason for men's vested interest in condemning women to a state of ignorance.

It cannot be rash to say that their only reason for excluding us from all the avenues to knowledge, is the fear of our excelling them in it $^{14}$.

Sophia's bitterness and indignation are sharply felt when she asks why learning should be considered completely unnecessary for women. She knows the answer: because women don't hold public office. And why don't they hold public office? Because they lack the necessary learning to do so! Her conclusion is devastating:

... why are they so industrious to debar us that learning, we have an equal right to with themselves, but for fear of our sharing, and outshining them in, those public offices they fill so miserably? ${ }^{15}$

The Sophia Pamphlets are practically a compendium of all the arguments and counter-arguments advanced since the Restoration on the upbringing and education of the fair sex. By the start of the 18th century, women are beginning to consider their educational needs in more concrete terms. There are intriguing ideas in this direction, such as the suggestion in one pamphlet that women should be taught physics in addition to cooking to enable them to judge foodstuffs in terms of their value for nutritional hygiene; languages and logic to give them as good a grasp of things as men; and medicine "to save as well as to destroy Men pleasantly".

Here, however, the main error of the feminist educational reformers becomes evident: the traditional rôle of the sexes is taken for granted. The idea that equal education might mean equal vocational opportunity was unthinkable. Lady Mary Wortley Montagu ${ }^{16}$, for instance, considered it "Divine Providence" that the professions were closed to women; the "philosophical ladies" and "she-clarks" were equally unpopular. Thus

${ }^{14}$ Woman not inferior to Man, p. 23.

15 Woman not inferior to Man, p. 28.

16 The Letters and Works of Lady Mary Wortley Montagu, ed. Lord Wharncliffe, with Additions etc. by W. Moy Thomas, 2 vols. (London, 1893). 
it is all the more astonishing that an Academy or College for young ladies and gentlewomen was suggested by a certain Edward Chamberlayne as early as $1671^{17}$. It should be kept in mind that Girton College (founded 1869) and Newnham College (founded 1871), both of which accepted women, were not fully integrated into Cambridge University until 1948, and that even today some Oxford colleges strictly refuse to admit anyone of the female sex. Chamberlayne's idea was taken up by Mary Astell, who took it one step further and suggested a College for Young Women, "a kind of monastery, if you will", in her pamphlet entitled A Serious Proposal to Ladies ${ }^{18}$. The educational goal is seen as preparation for marriage and motherhood. The suggestion is remarkable for the fact that it was by no means meant to remain mere theory, but to be put into practice and fully realized. The authoress wrote several circular letters appealing for donations to the foundation of just such a "religious retirement", and offered details as to what was to be taught and why.

Mary Astell's ideas were taken up by Mary Montagu, one of the few women of her century to possess the financial and social power to back the project successfully. The academy might have become a reality, had it not been for the lack of congenial patronage. The two socialites approached by Lady Montagu declined on the grounds that such a college would produce precisely the type of woman held up as an object of ridicule by the Femmes Savantes ${ }^{19}$. Philosophy and high education were not only a waste of time for women but might even be detrimental!

In 1697 the plan was taken up by Daniel Defoe, and the suggestions he made in his publication Project for an Academy of

17 E. Chamberlayne, An Academy of Colledge wherein Young Ladies and Gentlewomen may at a very Moderate Expense be Duly Instructed in the True Protestant Religion and in all Virtuous Qualities (London, 1671).

${ }_{18}$ Mary Astell, A Serious Proposal to the Ladies for the Advancement of their true and greatest Interest. In Two Parts. By a lover of the sex. Part I (London, 1694), Part II (London, 1697).

19 A. H. Upham, English Femmes Savantes at the End of the Seventeenth Century", JEGPh, 12 (1913), 262-276. 
$W{ }^{2} e^{20}$ are just as worthy of emulation today as they were when he proposed them. Defoe's concept called for a ladies' academy which would make the advantages of learning available to women. At the same time, however, he rejected the original ideas advanced by Mary Astell as smacking of nunneries and popism. Defoe had more of a Public School in mind, such as those already in existence for young men. In addition he placed far more weight on secular subjects, though still favouring the retention of religious instruction. He also emphasized the teaching of history and modern languages - especially French and Spanish.

After Defoe a number of leading public figures spoke out publicly in favour of institutions of higher education for women, such as Bishop G. Burnet, who generally thought little of feminine learnedness. In 1708 he suggested "something like monasteries without vows" for young ladies ${ }^{21}$. Thus there were voices crying out in the wilderness. The fact that no such academy or college was founded must be attributed to the intellectual climate of 18th-century England, which was not yet receptive for ideas of this kind.

And yet this is not to say that the ideas themselves were without effect, or that culture, civilization, and literature remained wholly untouched by them. In my opinion it is quite clear that the influence of those early pamphlets can be felt throughout the entire 18th century. In the wake of the Restoration, England was virtually flooded with feminist pamphlets, which left their trace long after the tide had turned and begun to ebb during the first few decades of the century. Indeed, it appears that the theoretical tracts were instrumental in steering the efforts of the most critical and dedicated women writers towards the field of creative literature.

20 D. Defoe, An Essay upon Projects (London, 1697, rpt. 1969), “An Academy for Women", p. 282-304.

${ }^{21}$ G. Burnet, History of Our Own Times (Edinburgh, 1728), IV, p. 205. 
II.

At the start of the 18th century, far more women began to take up writing, and their growing success extended to lyric poetry as well. The names of most women poets of that time have fallen into obscurity, unknown today, and their poems are long out of print. Not even the pertinent anthologies trouble to include them. And yet a thorough examination of the Poems by Eminent Ladies ${ }^{22}$, as well as the hundreds of little volumes of poetry published then, would undoubtedly reveal that women wrote as well and as appealingly as men in the 18th century (an age not particularly conducive to the lyric genre anyway.)

But this alone would not justify reviving the work of the 18thcentury women lyricists - many of whom, indeed, are not worth the effort. There ist, however, the additional fact - easily demonstrated - that the poetry written by women differs from that of their male counterparts: their topics and treatments are strongly marked by the quality of womanhood, of femininity - a fact already recognized in their time. Thus the editor of Poems by Eminent Ladies states in his preface:

... most of these Ladies (like many of our greatest male writers) were more indebted to nature for their success, than to education; and it was therefore thought better to omit those pieces, which too plainly betrayed the want of learning... ${ }^{23}$.

This sounds like an apology, and it was certainly not meant to be positive. The critical distance won by the passage of two and a half centuries, however, enables us to perceive that the lack of classical learning had a salutary effect. Most of the women write in a sober, transparent, and unpretentious style, without the mythological and allegorical hyperornamentation customary to the period. Above all, most of them dispense with the poetic diction so popular with their male contemporaries during the first half of the 18 th century ${ }^{24}$. The poems of Mrs. Barber, for

${ }^{22}$ Poems by Eminent Ladies (London, 1755).

${ }^{23}$ Poems by Eminent Ladies, Preface.

${ }^{24}$ K. H. Göller, "Die Poetic Diction des 18. Jahrhunderts in England", DVjs 38 (1964), 24-39; A. Janssen, "Frühe Lyrikerinnen des 18. Jahrhunderts in ihrem Verhältnis zur Poetik und zur Poetic Diction", Anglia, 99 (1981), 111-133. 
example, are an excellent illustration of what we might term "the feminine mode".

The differentia specifica of these women lyricists as opposed to the men was summed up with acute insight by Leigh Hunt in his Specimens of British Poetesses:

... we may observe the usual tendency of female writers to break through conventional commonplaces with some touches of nature. The least of them have an instinct of this sort, which does them honour, and sets them above the same class of writers in the other $\operatorname{sex}^{25}$.

In the work of nearly every single poetess up to 1750 we find at least one poem on the burden of being female - criticism of the tyranny of men both within and without the marriage bond, repression and inequality, lack of educational opportunities - in short, of the restrictions and stifling limitations which rule every aspect of women's way of life. Often we find complaints on the problem of being a woman writer as well, for even though the 18th century occasionally repaid women writers with admiration, they were generally regarded as an object of suspicion or worse. The response of the poetess often found expression in a sharp critique - sometimes framed in a poem or verse epistle of society's lack of understanding and particularly that of men. Often enough their attacks are directed at the representatives of the church, men whose ideas of womanhood and marriage - as a look at the popular genre of the Marriage Sermon will show remained stubbornly old-fashioned and patriarchal. Lady Chudleigh has one pastor say:

But Women were not for this province made [namely learnedness] And, should not our prerogative invade Whate'er they know shou'd be from us convey'd, We their preceptors and their guides shou'd prove And teach them what to hate, and what to love. But from our Sermons they no ill can learn ... ${ }^{26}$

${ }^{25}$ Hunt, "Specimens of British Poetesses", in: Works, Vol. II: Men, Women, and Books. A Selection of Sketches, Essays, and Critical Memoirs ... (London, 1876), pp. 257-286, here p. 270.

${ }^{26}$ Lady Chudleigh, "The Ladies Defence", in: Poems by Eminent Ladies, 2 vols. (Dublin, 1757), p. 173. 
Other authoresses ridicule the petty tyranny of men, attempt a humourous plea for more partnership between the sexes, and use this method to stimulate their readers to rethink their old concepts of 'man the monarch'. Mary Leapor, for instance, argues that it was not Eve but Adam rather, who first brought evil into the world. He usurped absolute dominance over the realms of the plants and animals and was justly expelled from Paradise for the sin. The manner in which Leapor's reasons for the expulsion deviate from those of the Bible is significant: not the desire for knowledge, but rather the abuse of authority leads to man's downfall. Eve is completely free from blame, for she has never possessed power nor been tempted by it. She suffered under Adam's oppression together with the animals and yet was worse off than they. Unlike them, she could not escape her persecutor.

The poems on marriage provide a close parallel to the theoretical tracts. In both cases the institution itself is never placed in doubt. Occasionally the uniform professions of marital dutifulness seem more like mere lip-service, or even - in some cases parody. Here and there it is difficult to tell the difference between directness and irony. Attacks against marriage itself are confined to lighter and lower forms of literature, couched in terms designed to appeal to the masses. Here aphorisms such as "only fools let themselves get trapped into marriage", or "marriage is bad business" abound. It is curious that this attitude should have been connected with male writers in particular, and that it has even been cited as evidence that it was men who wrote for popular consumption.

1750 marks a kind of turning point in the lyric poetry produced by women in England. As early as 1935, Viktor Lange remarked in his book Die Lyrik und ihr Publikum im England des 18. Jahrhunderts ${ }^{27}$ that literary taste underwent a change at about this time, turning more to moralizing entertainment, a sentimental attitude, and feminine triviality. Literary production has passed unmistakably from the aristocracy to the middle

${ }^{27}$ V. Lange, Die Lyrik und ihr Publikum im England des 18. Jahrhunderts. Eine geschmacksgeschichtliche Untersuchung über die englischen Anthologien von 1670-1780 (Weimar, 1935) [Literatur und Leben, Bd. 2]. 
and lower classes, a fact shown by developments in the contents of lyric anthologies between Jacob Tonson (1656-1736) and John Adams (1789). Such topics as "Moral Miscellanies", "Collections of Pretty Poems", "Poems for Young Ladies", and "Beauties of English Poesy" predominate. A typical case is Goldsmith's anthology, Poems for Young Ladies ${ }^{28}$, which subsumes the most popular poetry of the day under three categories: "devotional, moral, entertaining". Goldsmith's attitude towards the purpose of poetry and of this anthology is made explicit in his introduction: "In this little work", he says, "a lady may find the most exquisite pleasure, while she is at the same time learning the duties of life ${ }^{\star 29}$.

The year 1777 marks the height of poetic anthology publication with the appearance of Poems for Ladies, never before published and now first selected under the Inspection of a Lady. The publisher had recognized the money-making possibilities of the new feminism in literary taste. The critical comments of the Monthly Review are enlightening: "This is not for Ladies, but for milliners and mantuamakers and getters-up of small linen ${ }^{\text {“30 }}$. As for women writers, they seem to have adjusted quickly to the new market: the feminist controversy recedes more and more into the background, giving way to more emphasis on femininity and moralizing until about 1790 . The poetic anthologies at any rate contain no premonition of the explosion to come in Mary Wollstonecraft's $A$ Vindication of the Rights of Wo$\operatorname{man}^{31}$.

III.

The observations already made in the field of lyric poetry find their parallel in the 18th-century English drama produced by women. There are tangible differences between their work and that of men. Well-known and occasionally even successful plays

28 Poems for Young Ladies. Compiler: Oliver Goldsmith. In Three Parts: Devotional, Moral, and Entertaining. The whole being A Collection of the Best Pieces in our Language (London, 1767).

29 Poems for Young Ladies, Preface, p. III.

30 Monthly Review, 57, p. 327.

${ }^{31}$ M. Wollstonecraft, A Vindication of the Rights of Woman $\left({ }^{2} 1792\right.$, New York, 1975). 
were written by the Duchess of Newcastle, as well as by Aphra Behn, Mary Pix, Susanna Centlivre, Mary de la Rivière Manley, and Eliza Haywood. Some of them were astonishingly successful, particularly Mrs. Manley with The Royal Mischief ${ }^{32}$. Indeed, she was even parodied in an anonymous piece probably written by actors of the Drury Lane Theatre; they accused her of having outdone the best wits of the Restoration - the Alexanders, the Montezumas, and the Drawcansirs - and having eclipsed them all.

In typical Restoration Comedy, such as The Man of Mode, Love in a Wood, The Country Wife, The Old Batchelor, and The Way of the World, cuckoldry is practically the natural outcome of marriage ${ }^{33}$. That ancient institution is viewed as no more than a business arrangement in which love is less a help than a hindrance. Libertinism is a way of life, both for men, and to a lesser degree, for women. Precisely the opposite is true of those plays written by women during the same period. Here mutual trust and affection are seen as a necessary prerequisite - not only for a happy marriage, but also for relations between children and their parents. The Duchess of Newcastle - the first woman writer after the Restoration - provides an excellent example of this novel point of view. More worthy of note is Mrs. Aphra $\mathrm{Behn}^{34}$, the first Englishwoman to earn her living as a professional authoress. Her plays, like those of Mrs. Manley, are a condemnation of marriages based on purely financial considerations. Numerous other female playwrights stress the fact that marriage is of vital importance for a woman, something that decides the course of her entire life. All of them take it for granted that a woman can only find happiness and security in marriage. Thus the works of the female dramatists hardly ever contain the same supercilious, mocking contempt for marriage found so repeatedly in Restoration plays that it practically

32 M. Manley, The Royal Mischief (London, 1696).

${ }^{33} \mathrm{Sir}$ G. Etherege, The Man of Mode, or Sir Fopling Flutter (London 1676); W. Wycherly, Love in a Wood (London, 1671); ders., The Country Wife (1675); W. Congreve, The Old Batchelor (1693); ders. The Way of the World (1700).

${ }^{34}$ M. Summers, ed., The Works of Aphra Behn, 6 vols. (New York, 1967), plays vols. I-IV. 
amounts to a stereotype. In spite of the frivolity which ruled the day, we find the Hobbesian idea of dialectical opposition rejected by women playwrights in favour of something resembling the optimism later introduced by Shaftesbury - the "War between the Sexes" is replaced by an ideal of peaceful co-existence.

Several authoresses give voice to the theory that granted the necessary education, women would be capable of high intellectual achievement. A case in point is the figure of Valeria in Mrs. Centlivre's The Basset Table ${ }^{35}$. She is termed, a "naturalist" and amuses herself by cutting up frogs, fish, and flies in order to examine them under a microscope. Other female figures in the play belittle her activities as mere "Whimsies", or even denounce them as "Ridiculous, indeed, for Women; Philosophy suits our Sex as Jack-Boots would do."36

Valeria is the very picture of a feminist, and yet her creator, Mrs. Centlivre, views her with a critical eye and amused detachment. Thus she has Valeria kill her favourite dove in order to find out whether or not it has a gall bladder. She offers her cousin a valuable gem for a pet greyhound which she also wants to dissect. The ensuing commentaries reveal that she is liable to meet with resistance, even from those of her own sex. Lady Reveller remarks that there is reason to fear that she may, one day, go to the length of seeking scientific proof of Descartes' statement "that we are all machines" 37 . But love comes, even to Valeria. Somewhat prematurely she asks her wooer if one might truly assume "a world in every star"38. Thereupon the poor man takes to his heels, abandoning all further thoughts of marriage. He has no interest in a "she-clark" and her "philosophical gimcrack". As progressive as Mrs. Centlivre may be, she holds fast to the idea that no matter how learned the woman, love will triumph over science in the end.

The success of the female dramatists is astounding, and it is not least due to the fact that they discovered as early as the last

35 S. Centlivre, The Basset Table, A Comedy (Drury Lane, Nov. 20, 1705). In: The Dramatic Works of the Celebrated Mrs. Centlivre ..., 3 vols., vol. I, p. 199-258 (London, 1872, rpt. 1968).

36 The Basset Table, p. 217.

37 The Basset Table, p. 219.

38 The Basset Table, p. 221. 
decade of the 17th century that sentimentality was the coming mode in public taste and the new box-office attraction. Nearly all their plays include sentimental titbits that give the ladies in the 'loges' a chance "to enjoy the solace of tears". Thus one might have expected the Sentimental Comedy, or at least the Genteel Comedy to have become the special domain of women dramatists. Strangely enough, this was not the case. Myra Reynolds was one of the first to see the possibilities of this genre as the perfect medium for women. She remarks, however, that the successful sentimental comedies from The Conscious Lovers ${ }^{39}$ (1722) to False Delicacy ${ }^{40}$ (1768) were written by men playwrights. The reason for this is perfectly logical. Myra Reynolds says:

Tragedy was considered so inherently virtuous that the most highminded could find in it edification, and young girls who were forbidden attendance on comedies were freely allowed to witness tragedies. For this reason women writers with dramatic aspirations, but to whom the license of the comedy was distaste, applied themselves to tragedy ${ }^{41}$.

IV.

In contrast to Lyric Poetry and Drama, the Novel in England is a genre particularly congenial to women, both in production and in reception ${ }^{42}$. In terms of quantity, more novels were written by women than by men in the 18th century, and the most recent statistical investigations indicate that more than two thirds of those who read novels were women. It is not possible to deal here with the socio-economical, historical, and political factors which led to the development of the new genre, as well as to a new attitude towards literature in general. This particular aspect of the 18th century has been thoroughly treated dur-

${ }^{39}$ R. Steele, The Conscious Lovers (London, 1722).

${ }^{40}$ H. Kelly, False Delicacy (London, 1768).

${ }^{41}$ M. Reynolds, The Learned Lady in England 1650-1760 (Boston, New York, 1920), p. 437.

${ }^{42}$ S. Martin, The Eighteenth Century Novel Heroine - A Changing Ideal (Diss., Wien, 1977). 
ing the last few years (by Ian Watt ${ }^{43}$, inter alia). Very little, however, is known about the relationship between the feminist literature of the late 17 th and early 18 th centuries and the emergence of the novel. It is evident to me that there are a number of connections and that they are more than purely coincidental. The fact that the origins of the novel remain unidentified is largely due to our point of view. The point of departure for any study of the 18th-century novel is generally a preconceived set of classical types. This means that works of an entirely different literary character are measured with the false yardstick of, say, a Fielding or a Richardson.

In attempting to define the novel as a genre, however, we find that at the beginning of the 18 th century it embraced practically the entire range of prose forms in use at the time including the essay, travelogue, homily, and even lyric poetry. Of particular importance for the development of the novel as a genre were the so-called Scandal Chronicles, often termed "Secret Memoirs" or "Secret Chronicles". Mrs. de la Rivière Manley, Eliza Haywood, and others were responsible for introducing a new literary fashion - the roman à clef. Mrs. Manley's Secret History of Queen Sarah ${ }^{44}$ is written with all the cattiness of a woman (if you'll pardon the male chauvinism) - the story of the Duchess of Marlborough and at the same time a perfect picture of the mentality of the women of the time.

Manley's descriptions could well have been found in the theoretical tracts and pamphlets discussed at the beginning of this paper. In her New Atlantis ${ }^{45}$ she advocates better education for young girls. She complains bitterly of the double standard of morals for women and men, emphasizes woman's right to feel passion and the physical pleasures of love; she even goes to the extent of relating her own sexual adventures under the pseudo-

43 I. Watt, The Rise of the Novel (London, 1963, rpt. 1974).

${ }^{44}$ M. Manley, The Secret History of Queen Zarah and the Zarazians (London, 1705).

${ }^{45}$ M. Manley, Secret Memoirs and Manners of Several Persons of Quality, of both Sexes. From the New Atalantis an Island in the Mediterranean (London, 1709); in: The Novels of Mary Delariviere Manley, 2 vols., ed. P. Koster (Crainesville, 1971), I, p. 265-804. 
nym of Delia. Not only does she refuse to hide her "shame", but even uses her writing to flaunt it in the face of the world. In The Adventures of Rivella ${ }^{46}$, an outspokenly feminist work, she tells her own story under the pseudonym of the title figure. The entire book represents an embittered attack on the hypocrisy of the masculine moral code, which sees chastity as the highest good and yet condones the physical and psychological exploitation of women.

Scandalous novels grew more and more popular in the wake of Manley and Haywood ${ }^{47}$, and not merely because they were read as romans à clef and applied to contemporary figures and events. On the contrary, the reason lies in their fictional character, in the fact that they invoke a world in themselves, peopled with characters, problems, and situations which reflected the interests of their feminine readership. It is evident, for instance, that the same feminist topics were featured as those which figured in the pamphlets, in the early moral weeklies (Athenian Mercury), and in homiletic writing. Thus the Scandal Novels or Chronicles, as they were often called, are historically important. Not only did they represent a fictional counterpart to the feminist writing which appeared in the form of tracts and pamphlets; they also made the use of psychological, erotic, and sentimental elements in prose fiction popular, thus paving the way for the novels of Richardson. Richetty and other critics have noted that it is probably no coincidence that during the early 18th century most of the major authors of such memoirs were women, and that they were writing for a largely feminine audience.

As far as the emergence of the novel in the 18th century is concerned, I find it significant that the prose literature produced by women gradually loses its "feminist punch". The sentimental aspect of the novel - a factor already clearly recognizable as early as the Restoration - increasingly comes to dominate the elements of rationalism and common sense. The result is the melodramatic Novel of Sentiment, a genre which appealed

${ }^{46}$ M. Manley, The Adventures of Rivella; or, the History of the Author of the Atlantis ... (London, 1714).

47 J. Richetti, Popular Fiction before Richardson: Narrative Patterns (1739; Oxford, 1969). 
to a widening social spectrum, but altogether a kind of fiction more and more removed from the emancipatory ideals of the early 18 th century. A paradigm can even be found in the works of a single authoress, Eliza Haywood, whom we have already mentioned. In her youth she wrote in a libertinistic and frivolous vein, only to do a change-about-face after the middle of the century and to direct her writing towards a new market: “... she could strike her breast and cast her eyes heavenward with the best of them." ${ }^{48}$ Having achieved great popularity with the immorality of her early writing as a beginning, she made money towards the end of her life on the moralizing edification of devotional literature. She has rightly been called "the chameleon of English novelists" ${ }^{49}$.

After about the mid-century (1750) a period begins in England which has been termed "the age of courtesy books for women"50. By this time women have surrendered the claim to an identity of their own; they only exist for man. In the novel we find increasing discrimination against feminine sexuality. In Sarah Fielding's novel Ophelia for instance, we read that "a girl ought not to set eyes on a babe that was not of the feminine gender"51. If the sentimental heroine had only allowed herself a quiet weep, she now drowned her misery in a flood of tears. This is even true of Mary Wollstonecraft's only completed novel, $M a r y^{52}$, in which the heroine, continually resigned, saddened, and tearful, tries to adjust and conform to the demands she is subjected to in the evil world of men.

Generally it can be said that women discovered the novel as a medium of literary expression in the 18th century. This is not due to chance, but rather to the nature of the genre. The subject of the novel was the immediate experience of average human beings in private life. It offered an ideal opportunity for women,

${ }^{48}$ B. G. MacCarthy, The Female Pen, Women Writers, Their Contribution to the English Novel (1641-1744), 2 vols. (Oxford, 1944, $\left.{ }^{3} 1946\right)$, I. p. 241.

49 MacCarthy, The Female Pen, I, p. 241.

${ }^{50}$ H. Mews, Frail Vessels, Woman's Role in Women's Novels from Fanny Burney to George Eliot (London, 1969), p. 11.

51 S. Fielding, The History of Ophelia, 2 vols (rpt. in one; New York, London, 1974).

${ }^{52}$ M. Wollstonecraft, Mary, A Fiction ( ${ }^{1} 1788$, New York, 1977). 
who were being increasingly restricted to their homes, to express their social needs and deeds. Besides, it was not terribly difficult to write a novel in the 18th century. As Fielding said, nothing was necessary but paper, pens and ink. Thus the novel was a help in one's search for identity, and, at the same time, an opportunity to stimulate a change in thinking. The fact that the latter tendency was lost to view lies, I believe, in the usurpation of what was once a feminine genre by such men as Defoe and Fielding.

V.

During the last three decades of the 17th century and perhaps the first of the 18th century, we witness the climax of theoretical treatments of the problem of women's emancipation in England. This period sees the publication of important documents on the feminist question which are hardly known today and even in England evoked little response. Thus, for instance, Mary Wollstonecraft failed to acknowledge and was probably not acquainted with this body of writing. The 18th century, however, and particularly the early half, is a period of dissemination, popularization, and application of the theories advanced prior to 1700. Already through the Athenian Mercury the problem of better education for women had been popularized and made known to a broad spectrum of society. This development continued throughout the 18th century. Steele and Addison acquainted large numbers of the English populace with the feminist question and initiated developments which continued to have an influence up to the close of the century.

Even more important, perhaps, is the effect of the theoretical discussion on the field of creative literature. More and more women began to write lyric poetry after the last decades of the 17th century. Several of them voiced bitter complaints about the oppression, lack of equality, and discrimination to which they and their sex were subjected. While female dramatists played only a minor rôle in the 18 th century - in contrast to the Restoration period - women writers turned particularly to the genre of the novel. For this reason it has been called a feminine genre, both in its production and reception. Numerous critics 
have noted that women's literary achievements reached unparalleled heights in the medium of the novel.

In regard to the position of woman in society, the 18th century marks an obvious decline. The theoretical ideas postulated and the ideals put into practice at the beginning of the century degenerated, and so did the women who should have espoused them. Of course, this only applies to a small, elitist social circle which could afford the increasing aesthetization and sentimentalization. This meant a growth in the disparity between the social classes. The socialites became more and more tied to the confines of home and family; the desire for freedom and emancipation was replaced by the cultivation of feelings, "sensibility", and other supposedly feminine virtues. The end product of this generation-long development ist the nearly incapacitated, weak and sickly - but oh so womanly-tender Pre-Victorian! - the absolute antithesis to everything masculine.

Mary and her friend Ann have already reached this stage of development in Mary Wollstonecraft's novel Mary. This fact alone should make us sceptical towards the popular misconception that the Vindication of the Rights of Woman marked the starting point of women's emancipation in England. It is indisputable that this work represents an innovative development; the integral ideas, however, were already being formulated and popularized well before - after the Restoration and at the beginning of the 18th century. 